\title{
ACUTE TOXICITY OF METHYL PARATHION ON DAPHNIA LAEVIS (BIRGE, 1879) AND ITS IMPACT ON THE ACTIVITY OF FARMED FISH
}

\author{
KEPPELER, E. C. ${ }^{* 1}$, PLESE, L. P. M. $^{2} \&$ VIEIRA, L. J. S. ${ }^{3}$ \\ 1 Laboratório de Limnologia, Centro Multidisciplinar, Universidade Federal do Acre, Campus de \\ Cruzeiro do Sul, Glebas Formoso, Cruzeiro do Sul, Acre. \\ 2 Pró-Reitoria de Pesquisa, Inovação e Pós-Graduação, Instituto Federal do Acre, Rua Coronel \\ Alexandrino, 235, Bosque, Campus de Rio Branco, Acre. \\ 3 Laboratório de Ictiologia e Ecologia Aquática, Centro de Ciências Biológicas e da Natureza, Univer- \\ sidade Federal do Acre, Campus de Rio Branco, BR 364, Km 04, Distrito Industrial, Rio Branco, Acre. \\ *Corresponding author: erleikeppeler@gmail.com
}

\begin{abstract}
Keppeler, E.C.; Plese, L. P. M. \& Vieira, L. J. S. 2015. AcuteToxicity of Methyl Parathion on Daphnia laevis (Birge, 1879). Braz. J. Aquat. Sci. Technol. 19(1):33-38. eISSN 1983-9057. DOI: 10.14210/bjast.v19n1.p33-38 The present study was carried out to determine the short-term effective concentration $50 \%$ toxicity (EC50) of methyl parathion, and to evaluate whether Daphnia laevis has the potential to be used as test organism, in medium M4, using potassium dichromate as reference substance. Twenty neonates with aged less than $24 \mathrm{~h}$ were separated into four groups, exposed to concentrations of $5 \times 10-6 \mathrm{mg} \mathrm{L}-1,10 \times 10-6 \mathrm{mg} . \mathrm{L}-1,20 \times 10$-6 mg.L-1, $40 \times 10-6 \mathrm{mg} . \mathrm{L}-1,80 \times 10-6 \mathrm{mg} . \mathrm{L}-1$, plus a zero control, for $24 \mathrm{~h}$ in a static test. Spearman-Karber method was is adoted for estimating of the median effective concentration (EC50). The EC50 of methyl parathion in Daphnia was 19.4 × 10-6 mg.L-1. Thus, Daphnia laevis, in medium M4, has potential to be used as test organism using as reference substance the potassium dichromate.
\end{abstract}

Key words: Cladocera, EC50, Potassium dichromate.

Pesticides are chemicals produced for various purposes, such as in the areas of growing, storing and improving agricultural products in the field (Rosenzweig \& Liverman, 1992) and represent a serious threat to ecosystems (Howarth, 1983), because are used also in protecting natural and planted forests (Venzon et al., 2006), and of other ecosystems, such as water bodies.

The high concentration of fish cultivated always constitutes a factor that favors the emergence of diseases (Ueda et al., 2013). This is especially true in the case of intensive fish farms, because under conditions of confinement, fish are subjected to chronic stress, resulting above all in the deterioration of water quality. For example, methyl parathion is a toxic compound utilized to eliminate aquatic insect larvae, and very used in aquaculture (Almeida et al., 2005).

Daphnids are cladocerans freshwater microcrustaceans abundant in lakes and pond, because the animals are effective grazers on phytoplankton (major primary producer in lakes) and are favorite food for vertebrate and invertebrate predators (Pennak, 1978; Cooney, 1995). The species of cladocerans of genus Daphnia are the most often utilized for toxicity tests because of their high sensitivity to many toxic chemicals. Thus, it is reasonable to use Daphnia as a test organism.

The genus Daphnia (Cladocera, Daphnidae) is widely used as a test organism for acute and chronic tests (Hanazato, 1998; Kungolos et al., 1999) in the field of ecotoxicology. A standardized acute with
Daphnia test has been proposed by DIN (1981) e ISO (1982), where the test animals are used with $\leq 24 \mathrm{~h}$, in test with $24 \mathrm{~h}$ in photoperiod in dark.

Bioassays with reference substances are used for the evaluation of the sensitivity of the animal utilized in toxicological tests (Buikema Jr. et al., 1982). The toxicity of potassium dichromate is well known and your toxicity to invertebrates (Diamantino et al., 2000). The potassium dichromate was used as reference substance.

The acute toxicity of this reference substance potassium dichromate has been reported for many species of Daphnia (Persoone et al., 2009; Gopi et al., 2012). However, is not known the toxicity on Daphnia laevis in medium M4, a rich medium in salts and nutrients (Beatrici, 2004), standardized by the Organization for Economic Cooperation and Development (OECD, 2000).

Methyl parathion is a pesticide organophosphorous and is widely utilized in agriculture, it is also applied to eliminate aquatic insect larvae that prey on fish larvae (Silva et al., 1993; Fanta et al., 2003).

The present study was carried out to determine the short-term effective concentration $50 \%$ toxicity (EC50) of methyl parathion, and to evaluate whether Daphnia laevis has the potential to be used as test organism, in medium M4, using potassium dichromate as reference substance.

This work was performed at the Laboratory of Ecotoxicology of Agrochemicals \& Health, Department 
of Occupational Plant Protection, Faculty of Agricultural Sciences and Veterinary/UNESP, Jaboticabal associated with the Aquaculture Center of UNESP (CAUNESP).

The product chemicals used in this work were Potassium dichromate, as reference substance, and methyl parathion, as chemical compound, with active ingedient on the concentration of $600 \mathrm{~g} \cdot \mathrm{L}^{-1}$, belonging to toxicity class I, considered highly toxic.

The cultures consisted of 3 glass flasks containing about of 3 liters. Daphnia laevis was cultured in a fully defined medium M4 (OECD, 2000). Medium M4 was renew weekly. Cultures were maintained at $20^{\circ} \mathrm{C}$ under $12 \mathrm{~h}$ light: $12 \mathrm{~h}$ dark photoperiod. The food organism for the cladocerans was Scenedesmus subspicatus cultured in Chu medium (Chu, 1942).

Twenty neonates with aged less than $24 \mathrm{~h}$ (OECD, 1981; DIN, 1981; ISO, 1982), divided into four groups were exposed to each concentration for $24 \mathrm{~h}$ in a static test (US EPA, 1985), along with a control (Kungolos et al., 1999) in dark photoperiod (AFNOR, 1974, DIN, 1981, ABNT, 1987). The number of mobile and immobile specimens were recorded after $24 \mathrm{~h}$ (AFNOR, 1974; DIN, 1981; ISO, 1982, ABNT, 1987) and were calculated by the EC- values.

In order to evaluate Daphnia laevis as a potential test organism, two sensitivity tests were conducted
(ISO, 1982; DIN, 1989), using 4 and 5 treatments . Test solutions of potassium dichromate were prepared by diluting a stock solution of $600 \mathrm{mg} . \mathrm{L}^{-1}$. The tests were carried out in a acclimatized room at $20^{\circ} \mathrm{C}$ in the dark. Six logarithmically scaled concentrations were used, $0.05 \mathrm{mg} \cdot \mathrm{L}^{-1}, 0.10 \mathrm{mg} \cdot \mathrm{L}^{-1}, 0.20 \mathrm{mg} \cdot \mathrm{L}^{-1}, 0.40 \mathrm{mg} \cdot \mathrm{L}^{-1}, 0.80$ $\mathrm{mg} \cdot \mathrm{L}^{-1}, 1.60 \mathrm{mg}^{\mathrm{L}} \mathrm{L}^{-1}$ plus a zero control.

Test solutions of methyl parathion, were prepared by diluting a stock solution of $600 \mathrm{mg} \cdot \mathrm{L}^{-1}$. The tests were carried out in a acclimatized room at $20^{\circ} \mathrm{C}$ in the dark. Five logarithmically scaled concentrations were used, $5 \times 10-6 \mathrm{mg} \mathrm{L}^{-1}, 10 \times 10-6 \mathrm{mg} \cdot \mathrm{L}^{-1}, 20 \times 10$ $-6 \mathrm{mg} . \mathrm{L}^{-1}, 40 \times 10-6 \mathrm{mg} \cdot \mathrm{L}^{-1}, 80 \times 10-6 \mathrm{mg} \cdot \mathrm{L}^{-1}$, plus a zero control.

EPA's DOS program was used to perform the Spearman-Karber method (U.S. E.P.A., 1999), that is a program integrated with a plotting routine for obtaining plots of toxicity curves, which method is adoted for estimating of the median effective concentration (EC50) (Hamilton et al., 1977).

This program was employed to calculate the EC50 in Daphnia laevis for the 24-h acute toxicity test, at effective concentrations. In this test proportions no shows monotonically increasing, being $\mathrm{P}(1)<\mathrm{P}(2)$ (Hamilton et al., 1977, Hamilton et al., 1978). Descriptive statistics were also used, aiming to calculate the Pearson correlation coefficient (Zar, 1999).

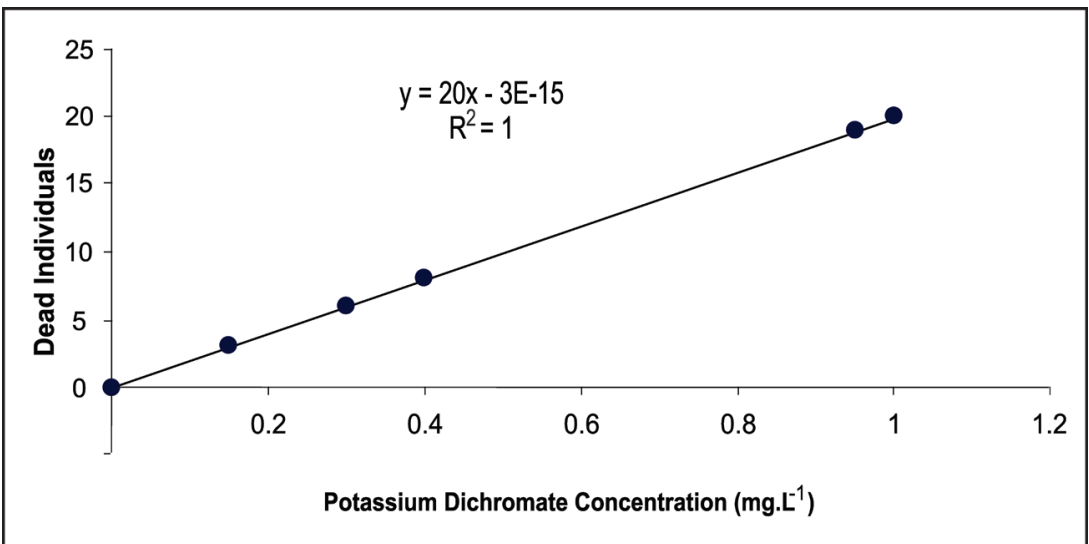

Figure 1. The correlation coefficient between dead individuals values for the potassium dichromate in 24h (Test 1).

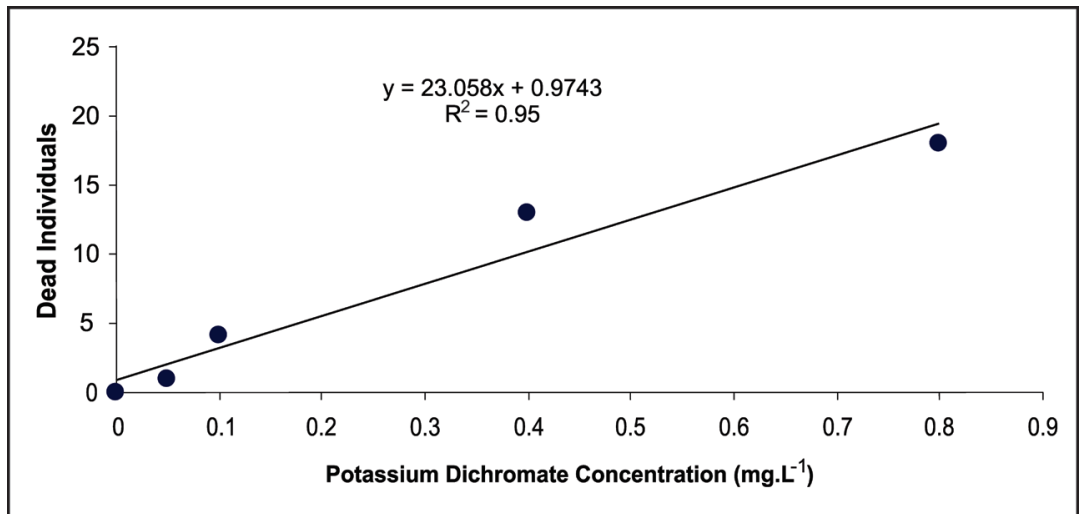

Figure 2. The correlation coefficient between dead individuals values for the potassium dichromate in 24h (Test 2). 
In the results, the sensitivity of Daphnia laevis to potassium dichromate shows an EC50 of 0.332 mg.L-1. Figures 1 and 2 also demonstrates a high pearson correlation coefficient of the effect of potassium dichromate on the dead individuals. The results with Daphnia laevis to potassium dichromate no did show notable difference in our study in regard to sensitivity to control and $0.05 \mathrm{mg} \cdot \mathrm{L}^{-1}$. With regard to others concentrations, only the results for concentration of 1.60 were more different.

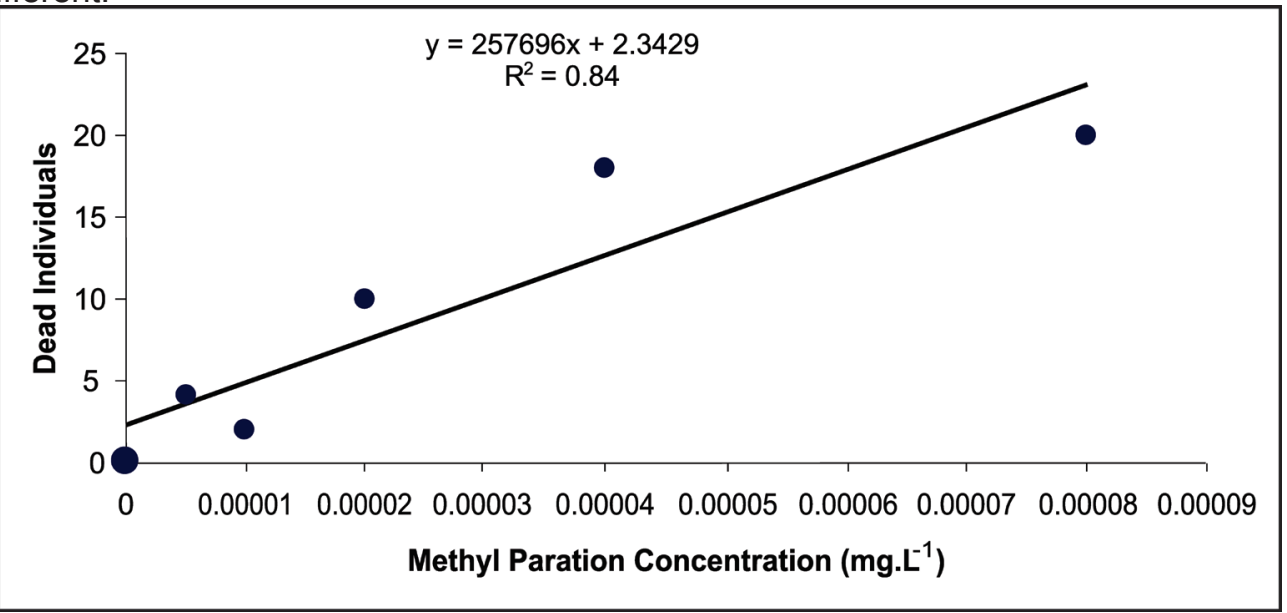

Figure 3. The correlation coefficient between dead individuals values for the Methyl parathion in 24h (Test 1).

A comparison of the acute toxicity of the values among species indicated that the potassium dichromate, in EC50 is different when compared with others species of Daphnia (Table 1). The different values of toxicities determined for test in different species of Daphnia may be related to several factors, considering, in this study, as the M4 medium and the species.

The methyl parathion EC50 for Daphnia laevis was much lower $\left(19.4 \times 10-6 \mathrm{mg}^{-\mathrm{L}^{-1}}\right)$ than the EC50$24 \mathrm{~h}$ for Daphnia magna at $9 \times 10-3 \mathrm{mg}$. L-1. (Kungolos
To the methyl parathion there was a positive correlation between concentration and mortality of individuals for methyl parathion and Daphnia laevis (Figure 3). The concentrations that caused significant effects, with respect to control, ranged from $5 \times 10-6$ to $80 \times 10-6 \mathrm{mg} \cdot \mathrm{L}^{-1}$ for methyl parathion. The toxicity of Daphnia to the Methyl parathion shows and EC50 of $19.4 \times 10-6 \mathrm{mg}^{-\mathrm{L}^{-1}}$.

Tabela 1: EC50 with potassium dichromate for species of Daphnia.

\begin{tabular}{|c|c|c|c|c|}
\hline Species & Medium & $\begin{array}{l}\text { Exposure time } \\
\text { (hr and } \min \text { ) }\end{array}$ & $\begin{array}{l}\text { EC50 } \\
\left(\mathrm{mg} \cdot \mathrm{L}^{-1}\right)\end{array}$ & \\
\hline D. similis & M4 & $48 \mathrm{~h}$ & $0.21-0.29$ & $\begin{array}{l}\text { Beatrici } \text { et al. } \\
(2006)\end{array}$ \\
\hline D. similis & ISO & $48 \mathrm{~h}$ & $0.04-0.08$ & $\begin{array}{l}\text { Beatrici et al. } \\
\text { (2006) }\end{array}$ \\
\hline D. magna & M4 & $48 \mathrm{~h}$ & $1.50-1.78$ & $\begin{array}{l}\text { Beatrici et al. } \\
(2006)\end{array}$ \\
\hline D. magna & ISO & $48 \mathrm{~h}$ & $0.81-0.97$ & $\begin{array}{l}\text { Beatrici et al. } \\
(2006)\end{array}$ \\
\hline D. magna & - & $1 \mathrm{~h}$ & 0.72 & $\begin{array}{l}\text { Janssen e } \\
\text { Persoone } \\
(1993)\end{array}$ \\
\hline D. magna & - & $48 \mathrm{~h}$ & 0.032 & $\begin{array}{l}\text { De Coen e } \\
\text { Jansen } \\
(1997)\end{array}$ \\
\hline D. laevis & M4 & $24 \mathrm{~h}$ & 0.332 & Present study \\
\hline
\end{tabular}

et al., 1999). It is known that small cladocerans like Ceriodaphnia are much more sensitive, for example to chlorpyrifos, than large Daphnia species probably due to their smaller size.

A comparison of the acute toxicity values among species indicated that the potassium dichromate in medium M4, showed an EC50 is approximately reduced by half when compared with others species of Daphnia.

On the other hand, the sensitivity of daphnids is also influenced by the used culture medium. Beatrici 
(2004) and Beatrici et al. (2006) concluded that D. magna and $D$. similis show more resistence to potassium dichromate in culture medium M4 than in ISO medium, which is a basic medium.

Senhorini et al. (1991) report that methyl parathion, with $60 \%$ active ingredient at concentrations between $0.25 \mathrm{mg} \cdot \mathrm{L}^{-1}$ and $0.50 \mathrm{mg} \cdot \mathrm{L}^{-1}$, decimated populations of Odonata and cladocerans, but copepods remained alive. Moreover, Gáradi et al. (1988) reports that Folidol eliminates Odonata at $0.5 \mathrm{mg} \cdot \mathrm{L}^{-1}$, but does not select the zooplankton.

Cruz et al. (2004) studied the effect of methyl parathion in Pacu (Piaractus mesopotamicus) recommended concentrations of $1.0 \mathrm{mg} . \mathrm{L}^{-1}$ for alevinos and $7.5 \mathrm{mg} . \mathrm{L}^{-1}$ for juveniles exposed to methyl parathion. This means that the quantities that would cause mortality to fish, are quite high, causing a much higher mortality in the plankton in the tank. Consequently, for this also lead problems toxics in wastes released in effluents in these doses, although recommended for fish farming would be lethal for the plankton present in dams, reservoirs, rivers and lakes. On the other hand, is well known that most of the applied pesticides are subject to many transport and conversion processes. Rovedatti et al. (2001) argues that organophosphates are of low persistence because of their short half-lives in aquatic environment.

Daphnia laevis, in medium M4, has potential to be used as test organism using as reference substance the potassium dichromate

In synthesis, the values utilized in baths of methyl parathion for farmed fish are highs for plankton, when the treatment of the fishes is carry out directly in water. The EC50 of methyl parathion to Daphnia laevis was much smaller than to other larger Daphnia species, when toxicity values were compared to other reported values from the literature, indicating that this species is more sensitive to the toxicants.

\section{REFERÊNCIAS}

ABNT. 1987. Associação Brasileira de Normas Técnicas. Água - Teste de toxicidade aguda com Daphnia similis, Claus (Cladocera, Crustacea) Método de ensaio. São Paulo, 31p. (Projeto 1: 62.05-001, novembro/1987, 1. Projeto de Norma). AFNOR. 1974. Association Française de Normalisation.

Essais de eaux - Détermination de l'inhibition de la mobilité Daphnia magna Strauss (Crustacés, Cladocère). Paris. 12p.

Almeida, L. C.; Aguiar, L. H. \& Moraes, G. 2005. Effect of methyl parathion on the muscle and brain acetylcholinesterase activity of matrinxã (Brycon cephalus). Cienc. Rural. 35 (6): 1412-1416.
APHA. 1991. American Public Health Association. Standard methods for the examination of water and wastewater. 17th ed. Washington, p. 81-143.

Buikema Jr, A. L.; Niederlehner, B. R. \& Cairns Jr, J. 1982. Biological monitoring part IV - Toxicity testing. Water Res. 16 (3): 239-262.

Chu, S. P. 1942. The influence of mineral composition of the medium of the growth of the planktonic algae. J. Ecol. 30: 284-325.

Beatrici, A. C. 2004. Avaliação da fertilidade e sensibilidade de Daphnia similis e Daphnia magna submetidas a diferentes tipos de dietas e meios de cultivo. Dissertação de Mestrado. UFRGS, Porto Alegre. 34pp.

Beatrici, A. C.; Arenzon, A, Coimbra, N. J. \& RayaRodriguez, M. T. 2006. Fertilidade e sensibilidade de Daphnia similis e Daphnia magna submetidas a diferentes cultivos. J. Braz. Soc. Ecotoxicol. 1 (2): 123-126.

Cooney, J. D. 1995. Freshwater tests. Pp. 71-102. In: Hand, G. M. Fundamentals of aquatic toxicology: effects, environmental fate, and risk assessment, Ed. G. M. Hand. Taylor and Francis, Washington. $1124 p$.

Cruz, C.; Machado-Neto, J. G.; Menezes, M. L. 2004. Toxicidade aguda do inseticida paration metílico e do biopesticida Azadiractina de folhas de neem (Azadirachta indica) para alevino e juvenil de pacu (Piaractus mesopotamicus). Pesticidas: Rev. Ecotoxicol. Meio Ambiente. 14 (1): 93-102.

De Coen, W.M. \& Janssen, C.R. 1997. The use of biomarkers in Daphnia magna testing: 2. Digestive activity in Daphnia magna exposed to sublethal concentrations of cadmium, chromium and mercury. Chemosphere. 25 (5): 1053-1076.

De Coen, W.M.; Vangheluwe, M.L. \& Janssen, C.R. 1998. The use of biomarkers in Daphnia magna testing: 3. Rapid toxicity testing of pure chemicals and sediment pore waters using ingestion and digestive enzyme activity. Chemosphere. 37 (13): 2677-2694

Diamantino, T.C.; Guilhermino, L.; Almeida, E. \& Soares, A.M.V.M. 2000. Toxicity of sodium molybdate and sodium Dichromate to Daphnia magna Straus Evaluated in acute, chronic, and Acetylcholinesterase inhibition tests. Ecotoxicol. Environ. Saf. 45 (3): 253-259.

DIN.1981. Deustsches Institut für Normung. Testverfahren mit wasserorganismen (Gruppe L) Bestimmung der Wirkung von Wasserinhaltsstoffen auf kleinkrebse. (Daphnien - Kurzzeittest) (L11). Berlim.

DIN.1989. Deutsches Institut für Normung, 1989. Deutsches institute für normung - testverfahren mit wasserorganismen (gruppe 1). Bestimming 
der nicht akut giftigen wirkung von abwasser gegenüber daphnien über verdünnungstufen norma din 38412 teil 30 (130). DIN 38412.

Fanta, E.; Rios, F.S.; Romão, S.; Vianna, A.C. \& Freiberger, S. 2003. Histopathology of the fish Corydoras paleatus contaminated with sublethal levels of organophosphorus in water and food. Ecotoxicol. Environ. Saf. 54: 119-130.

Gáradi, P.; Domarco, R.C.; Araújo, O.J. \& Pinheiro, C.W.L. 1988. Avaliação do uso de inseticidas (orgânicos fosforados) no combate às odonatas e na seleção zooplanctônica em piscicultura de alevinagem. In: CODEVASF - Companhia de Desenvolvimento do Vale do São Francisco. Estudos de piscicultura. $2^{\mathrm{a}}$ ed., Brasília: $71 \mathrm{p}$.

Gopi, R. A.; Ayyappan, S.; Chandrashehar, G.; Varma, K. K. \& Goparaju, A. 2012. Effect of potassium dichromate on the survival and reproduction. Bull. Environ. Pharmacol. Life Sci; 1 (7): 89-94.

Hamilton, M.A.; Russo, R.C. \& Thurston, V. 1977. Trimed Spearman-Karber method for estimating medial lethal concentrations in toxicology bioassays. Environ. Sci. Technol. 7: 714-719.

Hamilton, M. A. Russo, R.C. \& Thurston, V. 1978. Correction. Environ. Sci. Technol. 12: 417.

Howarth, F.G. 1983. Classical Biocontrol: Panacea or Pandora's Box. Hawaiian Entomol. Soc. 24 (2 and 3): 239-244.

Hanazato, T. 1998. Growth analysis of Daphnia early juvenile stages as an alternative method to test the chronic effect of chemicals. Chemosphere. 36 (8): 1903-1909.

ISO (International Organization for Standizartion). 1982. Water quality: Determination of the inhibition of the mobility of Daphnia magna Strauss (Cladocera, Crustacea). Paris, ISO, 2p.

Janssen, C. R. \& Persoone, G. 1993. Rapid toxicity screening tests for aquatic biota. 1. Methodology and experiments with Daphna magna. Environ. Toxic. Chem. 12: 711-717.

Kungolos, A.; Samaras, P.; Kipopoulou, A.M.; Zoumboulis, A. \& Sakellaropoulos, G. P. 1999. Interactive toxic effects of agrochemicals on aquatic organisms. Wat. Sci. Tech. 40: 357-364.

OECD (Organization for Economic Co-operatión and Development). 1981. Guidelines for testing of chemicals. Section 4: Effects of biotic systems. OECD, 15p.

OECD (Organization for Economic Co-operatión and Development). 2000. Daphnia sp., acute immobilisation test, revised proposal for updating guideline 202. Organization for the Economic Cooperation and Development, Paris, France.
Pennak, R.W. 1978. Fresh-water invertebrates of the United States. Wiley-Interscience Publication, New York. 803p.

Persoone, G.; Baudo, R.; Cotman, M.; Blaise, C.; Thompson, K. C.L.; Moreira-Santos, M.; Vollat, B.; Törökne, A. \& Han, T. 2009. Review on the acute Daphnia magna toxicity test - Evaluation of the sensivity and the precision of assays performed with organisms from laboratory cultures or hatched from dormant eggs. Knowl. Managt. Aquatic Ecosyst. 393 (01): 1-29.

Rosenzweig, C. \& Liverman, D. 1992. Predicted effects of climate change on agriculture: A comparison of temperate and tropical regions. In Global climate change: Implications, challenges, and mitigation measures, ed. S. K. Majumdar, 342-61. PA: The Pennsylvania Academy of Sciences.

Rovedatti, M.G.; Castañe, P.M.; Topalián, M.L. \& Salibián, A. 2001. Monitoring of organochlorine and organophosphorus pesticides in the water of the Reconquista River (Buenos Aires, Argentine). Wat. Res. 35: 3457-3461.

Senhorini, J.A.; Fontes, N.A.; Lucas, A.F.B. \& Santos, J.R.S. 1991. Larvicultura do pacu Piaractus mesopotamicus Holmberg, 1887, (Pisces, Characidae) em viveiros com e sem organofosforado (folidol 600). B. Cepta. 4 ( 2):11-22.

Silva, H.C.; Medina, H.S.G.; Fanta, E. \& Bacila, M. 1993. Sublethal effects of the organophosphate Folidol 600 (methyl parathion) on Callichthys callichthys (Pisce: Telestei). Comp. Biochem. Physiol. C. 105c (2): 197-201.

Ueda, B.H.; Karling, L.C.; Takemoto, R.M. \& Pavanelli, G.C. 2013. Parasites of the freshwater fish trade in Brazil: science metric study. Pesq. Vet. Bras. 33 (7): 851-854.

U.S. E.P.A. 1985. United States Environmental Protection Agency. Methods for measuring the acute toxicity of effluents to freshwater and marine organisms. USEPA, Cincinnati, 215p.

U.S. E.P.A. 1999. EPA Probit Analysis Program Used for Calculating LC/EC Values. Version 1.5, Ecological Monitoring Research Division, Environmental Monitoring Systems Laboratory, U.S. Environmental Protection Agency, Cincinnati , OHIO , 45628.

Venzon, M.; Rosado, M.C.; Pinto, C.M.F.; Duarte, V.S.; Euzébio, D.E. \& Pallini, A. 2006. Potential of alternative pesticides for control of broad mite on chili pepper "Malagueta". Horticultura Brasileira. 24 (2): 224-227.

Walz, N. 1993. Life History strategies of rotifers. Plankton regulation dynamics. Ecological studies. 98: 193-214. 
Keppeler, E.C. et al. (2015). AcuteToxicity of Methyl Parathion on Daphnia laevis (Birge, 1879)

Zar, J. H. 1999. Biostatistical Analysis, 4th ed. PrenticeHall, Inc., Upper Saddle River, NJ. 662pp.

Submetido: Fevereiro/2014

Revisado: Outubro/2015

Aceito: Fevereiro/2015 